\title{
Feasibility of Introducing Rice Based Four Crops Pattern in Rangpur Region of Bangladesh
}

\author{
M. Sh. Islam ${ }^{1}$, Zakia Yesmin ${ }^{2}$, M.A. Badshah and M.A. Ali ${ }^{3}$ \\ ${ }^{1}$ Agronomy Division \& ${ }^{3}$ Plant Pathology, Bangladesh Rice Research Institute, Gazipur-1701, \\ Bangladesh; ${ }^{2}$ Dept. of Agronomy, Hazi Mohammad Danesh Science \& Technology University, \\ Dinajpur, Bangladesh \\ *Corresponding author and Email: shahidul.brri@yahoo.com
}

Received: 8 March 2017

Accepted: 12 June 2017

\begin{abstract}
An experiment was conducted at Bangladesh Rice Research Institute (BRRI) Farm at Rangpur during July 2014 - June 2016 to introduce a 4-crops pattern with the aim of increasing cropping intensity, productivity, income and soil fertility. The experimental design was RCB with 3 replications. Four cropping patterns were tested which were: $\mathrm{CP}_{1}=\mathrm{T}$. Aman (BRRI dhan62)-Potato (Cardinal)Mungbean (BARI Mung-6)-T. Aus (BRRI dhan48), $\mathrm{CP}_{2}=\mathrm{T}$. Aman (BRRI dhan62)-Mustard (BARI Sorisha-14)-Mungbean (BARI Mung-6)-T. Aus (BRRI dhan48), Farmers' improved practice (FIP) = T. Aman (BR11)-Potato (Cardinal)-Maize (NK 40) and Farmers' general practice (FP) = T. Aman (BR11)-Boro (BRRI dhan28)- Fallow. In T. Aman 2014, BRRI dhan62 produced 3.87 and $3.85 \mathrm{t} \mathrm{ha}^{-1}$ grain yields under $\mathrm{CP}_{1} \& \mathrm{CP}_{2}$ (4 crops systems), respectively; BR11 gave grain yield of 4.62 and $4.36 \mathrm{t}$ $\mathrm{ha}^{-1}$ in FIP and FP (3 and 2 crop system), respectively. In T. Aman 2015, BRRI dhan62 produced grain yield of 4.23 and $4.19 \mathrm{t} \mathrm{ha}^{-1}$ in $\mathrm{CP}_{1}$ and $\mathrm{CP}_{2}$, and $\mathrm{BR} 11$ gave grain yield of 5.95 and $5.92 \mathrm{t} \mathrm{ha}^{-1}$ in FIP and FP, respectively. After T. Aman, potato yield was $24.66 \mathrm{t} \mathrm{ha}^{-1}$ in $\mathrm{CP}_{1}$ and $24.17 \mathrm{t} \mathrm{ha}^{-1}$ in FIP during 2014-15. In $\mathrm{CP}_{2}, 2^{\text {nd }}$ crop mustard yield was $1.16 \mathrm{tha}^{-1}$ and $3 \mathrm{r}^{\mathrm{d}}$ crop mungbean yield was only $0.98 \mathrm{t}$ ha ${ }^{1}$. In $\mathrm{CP}_{1}, 3 \mathrm{r}^{\mathrm{d}}$ crop mungbean yield was only $0.83 \mathrm{tha}^{-1}$. After potato in FIP, maize yield was $8.38 \mathrm{t} \mathrm{ha}^{-1}$. After T. Aman (BR11) in FP, grain yield of BRRI dhan28 was $5.42 \mathrm{t} \mathrm{ha}^{-1}$. The yield of BRRI dhan48 in $\mathrm{CP}_{1}$ and $\mathrm{CP}_{2}$ (as $4^{\text {th }}$ crop) was $4.5 \mathrm{t} \mathrm{ha}^{-1}$. Similar results of different crops were obtained in 2015-16. The rice equivalent yield (REY) was found to be $30.05 \& 35.95 \mathrm{t} \mathrm{ha}^{-1} \mathrm{yr}^{-1}$ in $\mathrm{CP}_{1}$ during $1^{\text {st }}$ and $2^{\text {nd }}$ year followed by FIP (23.92 \& $29.82 \mathrm{t} \mathrm{ha}^{-1} \mathrm{yr}^{-1}$, respectively). The REY was higher in $2^{\text {nd }}$ year compared to $1^{\text {st }}$ year. In 2014-15 the highest net return of Tk.2,42,560 ha ${ }^{-1}$ was observed in $\mathrm{CP}_{1}$ followed by FIP (Tk.1,58,380 ha-1); in 2015-16, the highest net return was in $\mathrm{CP}_{1}\left(\mathrm{Tk} .2,16,960 \mathrm{ha}^{-1}\right.$ ) followed by FIP (Tk.1,24,620 ha-1). Potato based cropping pattern was thus, the most suitable and profitable pattern in this area. T. Aman (BRRI dhan62)-Potato (Cardinal)-Mungbean (BARI Mung-6)-T. Aus (BRRI dhan48) may, therefore, be the most suitable and profitable cropping pattern in medium high lands of Rangpur region.
\end{abstract}

Keywords: Cropping pattern, profitability, rice equivalent yield, gross return, gross margin.

\section{Introduction}

Bangladesh is a densely populated country in the world with an area of $1,47,570$ sq. $\mathrm{km}$ with population of about 165 million which is also increasing at a rate of $1.37 \%$ per year (BBS, 2015). In Bangladesh, total cultivable land is 7.9 million hectare and it is shrinking day by day. The annual loss of agricultural land is about 
$0.73 \%$ due to construction of roads, houses, industrial infrastructure and therefore, there is a very little scope of increase cultivable land. But cropping intensity may be increased from the existing level of $192 \%$ (BBS 2015) by incorporating short duration crop varieties of rice, potato, mustard, mungbean and maize in existing rice based cropping pattern in Rangpur region.

Increase of cropping intensity in rice based cropping system is very important for food security, poverty alleviation and livelihood improvement. The main challenge of the new millennium is to increase $50 \%$ yield per unit land area through manipulating the limited land resource. In order to produce more food in limited area, the most important options are: i) increasing cropping intensity by producing three or more crops over the same piece of land in a year and ii) increasing production efficiency of the individual crop by using optimum management practices.

Although, Bangladesh is nearly self-sufficient in rice production, other foods such as wheat, pulses, oil crops etc. are still deficit to a large extent. Recently, with the development of short duration varieties of rice, opportunity has been created to accommodate mustard, potato, pulses, maize etc. following rice in same piece of land in a year. Mustard production can be increased up to $20-23 \%$ only by replacing traditional variety with high yielding short duration varieties like BARI Sarisha-14 and BARI Sarisha-15 in the existing rice based cropping system (OFRD, 2014). Pulses are short duration important legume crops which are generally grown with less fertilizer since they can meet their $\mathrm{N}$ requirement by symbiotic fixation of atmospheric $\mathrm{N}$ in soil (Islam, 1991). Pulses also supply a substantial amount of $\mathrm{N}$ to the succeeding non-legume crops grown in rice based cropping system (Sharma and Prasad, 1999).

Thus development of short duration crop varieties by research organizations created and produces more yields of these crops on limited land. The present experiment was therefore, undertaken to evaluate the feasibility of increasing cropping intensity and productivity by growing four crops in a year in the same piece of land by incorporating short duration crop varieties in the existing rice based cropping systems of Rangpur region.

\section{Materials and Methods}

\subsection{Experimental sites and seasons}

The experiment was conducted in medium high land of BRRI regional station farm, Rangpur (latitude $24^{\circ} 88^{\prime} \& 26^{\circ} 33^{\prime} \mathrm{N}$ and longitude $88^{\circ} \&$ $90^{\circ} \mathrm{E}, \mathrm{AEZ} 3$ ) from July 2014 to June 2016 . The soil was loamy with $\mathrm{pH} 6.6$, organic matter $1.8 \%$, total $\mathrm{N} 0.1 \%, \mathrm{P} 31 \mathrm{ppm}, \mathrm{K} 0.14 \mathrm{~m}$ equi/100 g soil, S $6.34 \mathrm{ppm}$ and $\mathrm{Zn} 3.74 \mathrm{ppm}$.

\subsection{Experimental design and treatments}

The experiment was laid-out in a randomized complete block design (RCBD) with 3 replications. The unit plot size was $8 \mathrm{~m} \times 6 \mathrm{~m}$ where the field layout was permanent and all plots were divided with $20 \mathrm{~cm}$ height and $25 \mathrm{~cm}$ width strong levee to avoid soil fertility contamination. The tested cropping pattern was: $\mathrm{CP}_{1}=\mathrm{T}$. Aman-Potato-Mungbean-T. Aus, $\mathrm{CP}_{2}=$ T. Aman- Mustard -Mungbean-T. Aus, FIP = T. Aman-Potato-Maize, FP $=\mathrm{T}$. Aman-FallowBoro.

\subsection{Fertilizer management and cultural practices}

One $\mathrm{t} \mathrm{ha}^{-1}$ farm yard manure was applied in the experimental plots prior to starting experiment. The planting schedules, seed rate, spacing, and fertilizer rates and other agronomic practices are shown in Appendix 1.

N, P, K, S and Zn were applied from Urea, TSP, MoP, Gypsum and $\mathrm{ZnSO}_{4}$, respectively; B was applied from Boric acid in potato, mustard, mungbean and maize. Thiovit ( $S$ containing fungicide as growth stimulating agent), Mancozeb (to control late blight), Acimix (to control soil born pest) were applied in potato. 
Rajdhan was applied in rice and maize to control stem borer. Acimix was also applied in mustard and mungbean to control aphid and other pests. Soil from each plot was collected prior and after cultivation and tested to indicate major soil nutrients status.

\subsection{Climatic conditions}

Rangpur region is comparatively cold prone area with prolong winter. Sometimes, temperature goes below the critical level $\left(10^{\circ} \mathrm{C}\right)$ during winter rice cultivation. Winter starts from mid November and continued up to mid March. Monthly maximum and minimum air temperature, total rainfall, relative humidity and solar radiation data are presented for each year in Fig.1A \& B and 2A \& B. The monthly mean maximum temperature was the highest $\left(33.1^{\circ} \mathrm{C}\right)$ in July 2014 and the lowest monthly mean temperature $\left(11.4^{\circ} \mathrm{C}\right)$ was recorded in January 2015 (Fig. A). The minimum and maximum rainfall varied from 1.4 to $342 \mathrm{~mm}$ per month which was not uniformly distributed. The highest monthly total rainfall $(342 \mathrm{~mm})$ was recorded in August 2014 (Fig. B). Again the monthly mean maximum temperature was the highest $\left(32.8^{\circ} \mathrm{C}\right)$ in July 2015 and the lowest monthly mean temperature $\left(10.8^{\circ} \mathrm{C}\right)$ was recorded in January 2016 (Fig. A). The monthly rainfall varied from 0 to $676 \mathrm{~mm}$ which was not uniformly distributed. The highest monthly total rainfall (676 mm) was recorded in August 2015 (Fig. B).

\subsection{Sampling techniques, yield estimation and statistical analysis}

Standard data collection technique and procedure were followed for each crop. For rice, $5.0 \mathrm{~m}^{2}$ (excluding border) area was harvested at maturity for determining grain yield. Grain moisture was measured from each plot sample and yield was determined at $14 \%$ moisture content. Twelve hills were harvested from each plot to measure plant height, tiller number $\mathrm{m}^{-2}$, and to calculate yield components, harvest index and sterility. For other crops, total plot $\left(48 \mathrm{~m}^{2}\right)$ was harvested to determine yield.

\subsection{Rice equivalent yield (REY)}

To compare and evaluate different cropping pattern, the yield of all non rice crops was converted into rice equivalent on the basis of yield and prevailed market price of respective crop (Verma and Modgal, 1983).

$$
\begin{aligned}
& \operatorname{REY}\left(\mathrm{t} \mathrm{ha}^{-1} \mathrm{yr}^{-1}\right)= \\
& \text { Individual crop yield } \times \text { Unit price of that crop } \\
& \text { Unit price of rice crop }
\end{aligned}
$$

\subsection{Economic analysis}

To determine the gross margin, total inputs (total variable cost) and outputs cost were calculated considering the prevailed market price. Gross return, gross margin and BCR were determined.

Data collected from harvested rice and analysis of soil was analyzed by using Crop-stat program.

\section{Results and Discussion}

\subsection{Yield of crops}

In T. Aman 2014, BRRI dhan62, the shortest growth duration (100 days) variety produced $3.87 \& 3.85 \mathrm{t} \mathrm{ha}^{-1}$ grain yield in $\mathrm{CP}_{1}$ and $\mathrm{CP}_{2}$ (four crops system), respectively. In FIP and FP ( 3 and 2 crops system), BR11 gave grain yield of $4.62 \& 4.36 \mathrm{t} \mathrm{ha}^{-1}$, respectively (Table 1 ).

After T. Aman (BRRI dhan62) harvest, the yield of $2^{\text {nd }}$ crop potato in $\mathrm{CP}_{1}$ was $24.66 \mathrm{t} \mathrm{ha}^{-1}$ (early). After BR11 harvest in FIP, the potato yield was $24.17 \mathrm{t} \mathrm{ha}^{-1}$ (late). There was no yield difference in early and late in that condition, but the market price of early potato was higher (Tk. $5 \mathrm{~kg}^{-1}$ ). In $\mathrm{CP}_{2}, 2^{\text {nd }}$ crop mustard yield was $1.16 \mathrm{t} \mathrm{ha}^{-1}$. Second crop mungbean yield in $\mathrm{CP}_{1}$ was only $0.98 \mathrm{t} \mathrm{ha}^{-1}$. In $\mathrm{CP}_{2}, 3^{\text {rd }}$ crop mungbean yield was only $0.83 \mathrm{t} \mathrm{ha}^{-1}$. In FIP, $3^{\text {rd }}$ crop maize yield was $8.38 \mathrm{t} \mathrm{ha}^{-1}$. In FP, $2^{\text {nd }}$ crop BRRI dhan 28 gave $5.42 \mathrm{t} \mathrm{ha}^{-1}$ grain yields (Table 2 ). The grain yield of $4^{\text {th }}$ crop BRRI dhan 48 in $\mathrm{CP}_{1}$ and $\mathrm{CP}_{2}$ (in $\mathrm{T}$. Aus season) was $4.5 \mathrm{t} \mathrm{ha}^{-1}$ with 105 days growth duration. 

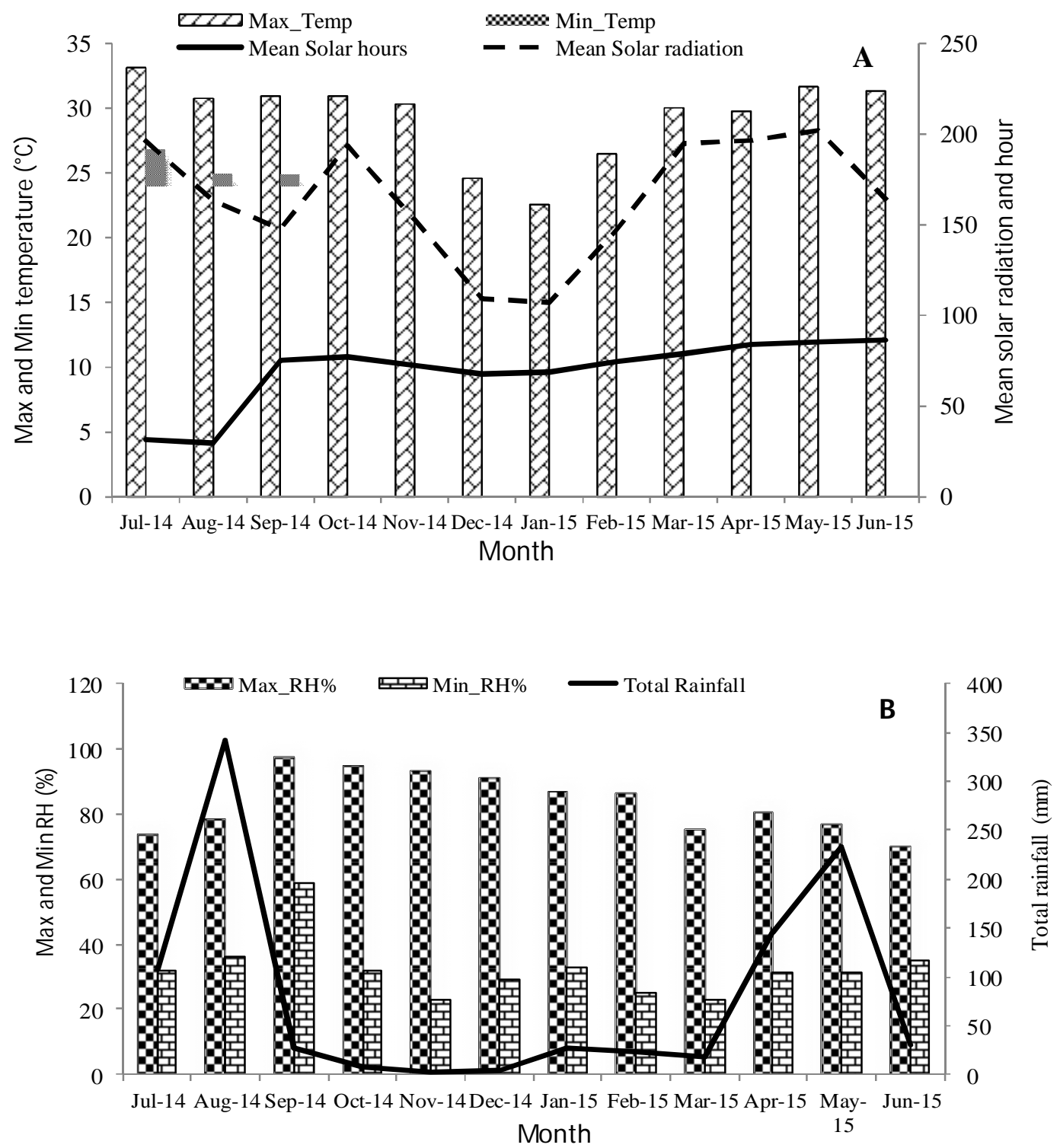

Figure 1. Weather data of BRRI Rangpur Station from July 2014 to June 2015 (Monthly Average) 

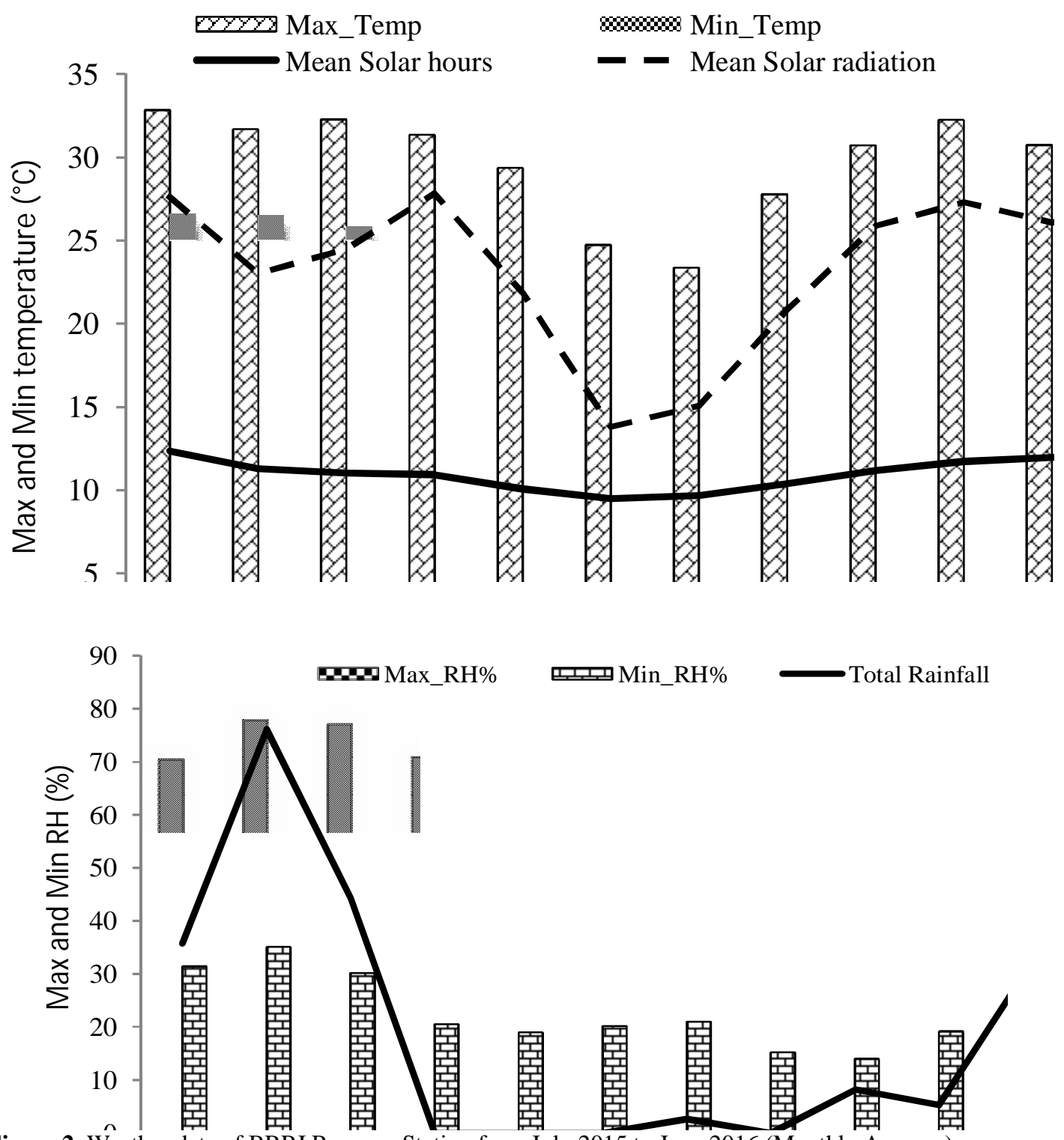

Figure 2. Weather data of BRRI Rangpur Station from July 2015 to June 2016 (Monthly Average) 


\subsection{Rice equivalent yields, gross return, gross margin and $B C R$}

$\mathrm{CP}_{1}$ obtained the highest rice equivalent yield (30.05 $\mathrm{t} \mathrm{ha}^{-1} \mathrm{yr}^{-1}$ ) with the highest economic return followed by FIP (23.92 $\mathrm{t} \mathrm{ha}^{-1} \mathrm{yr}^{-1}$, Table 2). Poor yield of mustard and mungbean resulted the lower REY of 13.94 even with 4 crops $\left(\mathrm{CP}_{2}\right)$.
Total cost of production and net return under different cropping pattern were estimated and presented in Table 3. The result showed that the highest net return was observed (Tk.242,560 ha ${ }^{1}$ ) in $\mathrm{CP}_{1}$ (4 crops with early potato and BRRI dhan62) followed by FIP (Tk.1,58,380 ha ${ }^{-1}$ ). The highest BCR was also observed in CP1 followed by FIP (Table 3 ).

Table 1. Grain yield and yield components of BRRI dhan62 and BR11, T. Aman, 2014

\begin{tabular}{ccccccccc}
\hline $\begin{array}{c}\text { C. } \\
\text { Pattern }\end{array}$ & $\begin{array}{c}\text { Plant ht. } \\
(\mathrm{cm})\end{array}$ & $\begin{array}{c}\text { Tiller } \\
\text { hill }^{-1}\end{array}$ & $\begin{array}{c}\text { Panicle } \\
\mathrm{m}^{-2}\end{array}$ & $\begin{array}{c}\text { Grain } \\
\text { panicle }^{-1}\end{array}$ & $\begin{array}{c}1000 \\
\mathrm{GW}(\mathrm{g})\end{array}$ & $\begin{array}{c}\text { Yield } \\
\left(\mathrm{t} \mathrm{ha}^{-1}\right)\end{array}$ & $\begin{array}{c}\text { Sterility } \\
(\%)\end{array}$ & HI \\
\hline $\mathrm{CP}_{1}$ & 101 & 11 & 250 & 71 & 23.05 & 3.87 & 17.2 & 0.46 \\
$\mathrm{CP}_{2}$ & 99 & 12 & 250 & 61 & 23.15 & 3.85 & 22.8 & 0.46 \\
$\mathrm{FIP}$ & 95 & 10 & 200 & 89 & 23.71 & 4.62 & 19.3 & 0.48 \\
FP & 95 & 9 & 200 & 87 & 23.61 & 4.36 & 24.9 & 0.47 \\
\hline $\mathrm{LSD}_{0.05}$ & 2.92 & 1.2 & 20.73 & 15.36 & $\mathrm{NS}$ & $\mathrm{NS}$ & 8.49 & $\mathrm{NS}$ \\
$\mathrm{CV} \%$ & 1.50 & 6.33 & 9.8 & 9.83 & 3.09 & 7.05 & 13.36 & 3.0 \\
\hline
\end{tabular}

* $\mathrm{CP}_{1}$ and $\mathrm{CP}_{2}$ : BRRI dhan62, FIP and FP: BR11

Table 2. Rice equivalent yield under different cropping pattern, 2014-15, BRRI Rangpur

\begin{tabular}{|c|c|c|c|c|c|}
\hline $\begin{array}{c}\mathrm{C} . \\
\text { pattern }\end{array}$ & $\begin{array}{c}1^{\text {st }} \text { crop yield } \\
\left(\mathrm{t} \mathrm{ha}^{-1}\right)\end{array}$ & $\begin{array}{c}2^{\text {nd }} \text { crop yield } \\
\left(\mathrm{t} \mathrm{ha}^{-1}\right)\end{array}$ & $\begin{array}{c}3^{\text {rd }} \text { crop yield } \\
\left(\mathrm{t} \mathrm{ha}^{-1}\right)\end{array}$ & $\begin{array}{c}4^{\text {th }} \text { crop yield } \\
\left(\mathrm{t} \mathrm{ha}^{-1}\right)\end{array}$ & $\begin{array}{c}\text { REY } \\
\left(\mathrm{t} \mathrm{ha}^{-1} \mathrm{yr}^{-1}\right)\end{array}$ \\
\hline $\mathrm{CP}_{1}$ & $\begin{array}{l}\text { BRRI dhan62 = } \\
3.87\end{array}$ & Potato $=24.66^{*}$ & $\begin{array}{l}\text { Mungbean = } \\
0.98\end{array}$ & $\begin{array}{l}\text { BRRI dhan } 48 \\
=4.5\end{array}$ & 30.05 \\
\hline $\mathrm{CP}_{2}$ & $\begin{array}{l}\text { BRRI dhan62= } \\
3.85\end{array}$ & $\begin{array}{l}\text { Mustard = } \\
1.16^{* *}\end{array}$ & $\begin{array}{l}\text { Mungbean= } \\
0.86\end{array}$ & $\begin{array}{l}\text { BRRI dhan } 48 \\
=4.5\end{array}$ & 13.94 \\
\hline FIP & $\mathrm{BR} 11=4.62$ & Potato $=24.17$ & Maize $=8.38$ & - & 23.92 \\
\hline $\mathrm{FP}$ & $\mathrm{BR} 11=4.36$ & Boro $=5.42$ & - & - & 9.78 \\
\hline
\end{tabular}

Considering that, $* 1.0 \mathrm{t}$ Potato $=0.94 \mathrm{t}$ rice (early), $0.63 \mathrm{t}$ rice (late) $* * 1.0 \mathrm{t}$ Mustard $=2.5 \mathrm{t}$ rice, $1.0 \mathrm{t}$ Mungbean $=$ $3.13 \mathrm{t}$ rice, $1 \mathrm{t}$ Maize $=0.5 \mathrm{t}$ rice $\left(\right.$ Rice $=$ Tk. $16 \mathrm{~kg}^{-1}$, Potato $=$ Tk. $15 \mathrm{~kg}^{-1}$-early, Potato $=$ Tk. $10 \mathrm{~kg}^{-1}$-late, Mustard $=$ Tk.40 kg-1, Mungbean= Tk. $50 \mathrm{~kg}^{-1} \&$ Maize $=$ Tk. $8 \mathrm{~kg}^{-1}$ at harvest).

Table 3. Total cost of production and net return under different cropping pattern (Tk. ha $\left.{ }^{-1}\right)$, BRRI Rangpur, 2014-15

\begin{tabular}{|c|c|c|c|c|c|c|c|c|c|c|c|c|}
\hline \multirow{2}{*}{$\begin{array}{c}\text { C. } \\
\text { pattern }\end{array}$} & \multicolumn{2}{|c|}{$1^{\text {st }}$ Crop } & \multicolumn{2}{|c|}{$2^{\text {nd }}$ Crop } & \multicolumn{2}{|c|}{$3^{\text {rd }}$ Crop } & \multicolumn{2}{|c|}{$4^{\text {th }}$ Crop } & \multicolumn{2}{|c|}{ Total } & \multirow{2}{*}{ GM } & \multirow{2}{*}{$\begin{array}{c}\mathrm{BC} \\
\mathrm{R}\end{array}$} \\
\hline & TVC & GR & $\mathrm{VC}$ & GR & TVC & GR & TVC & GR & TVC & GR & & \\
\hline $\mathrm{CP}_{1}$ & 4080 & 320 & 6000 & 370 & 35200 & 49120 & 65440 & 81 & 50800 & 3280 & & 1.69 \\
\hline $\mathrm{CP}_{2}$ & 30 & & 0 & & 35200 & 43 & 5440 & 81120 & 00 & 0 & & 1.22 \\
\hline FIP & 920 & & 0560 & 24 & 65440 & 67200 & - & - & 323840 & 39 & & 1.2 \\
\hline FP & 7920 & 93100 & 101680 & 106800 & . & . & - & - & 179520 & 187680 & 15580 & 1.05 \\
\hline
\end{tabular}

$\mathrm{TVC}=$ Total variable cost, $\mathrm{GR}=$ Gross return and $\mathrm{GM}=$ Gross margin 
Table 4. Soil fertility status as influenced by different cropping pattern, BRRI Farm, Rangpur, 2014-15

\begin{tabular}{cccccccc}
\hline Treat & $\mathrm{pH}$ & $\mathrm{OM} \%$ & $\begin{array}{c}\text { Total } \\
\mathrm{N} \%\end{array}$ & $\mathrm{P}(\mathrm{ppm})$ & $\begin{array}{c}\mathrm{K}(\text { meqi/100 } \\
\text { g soil) }\end{array}$ & $\mathrm{S}(\mathrm{ppm})$ & $\mathrm{Zn}(\mathrm{ppm})$ \\
\hline Initial soil & 6.60 & 1.86 & 0.10 & 31.15 & 0.14 & 6.34 & 3.74 \\
$\mathrm{CP}_{1}$ & 6.35 & 1.94 & 0.10 & 57.13 & 0.17 & 23.84 & 2.44 \\
$\mathrm{CP}_{2}$ & 6.35 & 2.33 & 0.11 & 50.95 & 0.16 & 15.78 & 2.90 \\
$\mathrm{FIP}$ & 6.59 & 1.73 & 0.08 & 40.52 & 0.14 & 10.63 & 2.50 \\
$\mathrm{FP}$ & 6.43 & 2.44 & 0.12 & 42.34 & 0.13 & 13.62 & 3.41 \\
\hline $\mathrm{LSD}_{0.05}$ & $\mathrm{NS}$ & $\mathrm{NS}$ & $\mathrm{NS}$ & $\mathrm{NS}$ & $\mathrm{NS}$ & 9.67 & $\mathrm{NS}$ \\
\hline
\end{tabular}

\subsection{Effect of cropping pattern on soil nutrient status}

There was no significant change in soil $\mathrm{pH}$, organic matter, total $\mathrm{N}, \mathrm{P}, \mathrm{K}$ and $\mathrm{Zn}$ content were observed. Increasing tendency was observed in $\mathrm{S}$ in different treatments (Table 4) compared to initial soil.

\subsubsection{Crop yields}

In T. Aman 2015, BRRI dhan62 in $\mathrm{CP}_{1}$ and $\mathrm{CP}_{2}$ (four crops system) gave 4.23 and $4.19 \mathrm{t} \mathrm{ha}^{-1}$ grain yields, respectively. In FIP and FP ( 3 and 2 crops system), the common variety BR11 gave 5.95 and $5.92 \mathrm{t} \mathrm{ha}^{-1}$ grain yield, respectively (Table 5).

As $2^{\text {nd }}$ crop Potato in $\mathrm{CP}_{1}$ gave the yield of 25.83 $\mathrm{t} \mathrm{ha}^{-1}$ (early) and FIP, the potato yield was 26.80 t ha ${ }^{-1}$ (late). In $\mathrm{FP}_{2}, 2^{\text {nd }}$ crop mustard yield was only $0.93 \mathrm{t} \mathrm{ha}^{-1}$. As $3^{\text {rd }}$ crop mungbean in $\mathrm{CP}_{1}$, the yield was only $0.61 \mathrm{t} \mathrm{ha}^{-1}$ and in $\mathrm{CP}_{2}$, the yield was only $0.71 \mathrm{t} \mathrm{ha}^{-1}$. In FIP $3^{\text {rd }}$ crop maize yield was $8.75 \mathrm{t} \mathrm{ha}^{-1}$. In FP, $2^{\text {nd }}$ crop BRRI dhan 28 gave grain yield of $6.21 \mathrm{t} \mathrm{ha}^{-1}$ (Table 6). The $4^{\text {th }}$ crop yield of BRRI dhan 48 in $\mathrm{CP}_{1}$ and $\mathrm{CP}_{2}(\mathrm{~T}$. Aus season) were 3.63 and $3.80 \mathrm{t} \mathrm{ha}^{-1}$, respectively.

\subsubsection{Rice equivalent yields, net return and BCR}

The highest rice equivalent yield (REY) was observed in $\mathrm{CP}_{1}\left(35.95 \mathrm{t} \mathrm{ha}^{-1} \mathrm{yr}^{-1}\right)$ followed by FIP (29.82, Table 7). The lowest REY was observed in $\mathrm{CP}_{2}$ (13.87 $\mathrm{tha}^{-1} \mathrm{yr}^{-1}, 4$ crops) and FP (12.13). The lowest REY $\mathrm{CP}_{2}$ was mainly due to lower yield of mustard $\left(0.93 \mathrm{t} \mathrm{ha}^{-1}\right)$ and mungbean $\left(0.71 \mathrm{t} \mathrm{ha}^{-1}\right)$. Similarly, the highest gross margin (GM) was observed in $\mathrm{CP}_{1}$ (Tk.2,16960 ha ${ }^{-1}$ ) followed by FIP (Tk.1,31,620 $\mathrm{ha}^{-1}$, Table 7) and the lowest GM was observed in $\mathrm{CP}_{2}$ (Tk. $19040 \mathrm{ha}^{-1}$ and FP 20,900 Tk. ha ${ }^{-1}$ ). Similarly, the highest $\mathrm{BCR}$ was found in $\mathrm{CP}_{1}$ followed by FIP. So, even growing 4 crops with mustard and mungbean did not increase the RYT and gross margin.

\subsubsection{Effect of cropping pattern on soil properties}

There was no significant change in soil $\mathrm{pH}$ and total N, little change in soil organic matter. The amount of $\mathrm{P}, \mathrm{K}, \mathrm{S}$ and $\mathrm{Zn}$ were increased in all treatments compared with initial soil and in some treatments compared with previous year soil analysis results (Table 8), it might be due to the residual effect of applied fertilizers in different crops.

The study was conducted where there is a scope to introduce 4 crops in same land in a year. The main limitations for introducing 4 crops in a cropping pattern are the tight schedule for crop establishment, natural calamities (rain, cold, high temperature, excess/ inadequate moisture in the soil etc.) and seed availability of different crops. However, it is possible to introduce 4 crops in a cropping pattern if we overcome those limitations. A number of reports on different cropping patterns are available in Bangladesh (Khan et al., 2005, and Nazrul et al., 2013) where an additional crop could be introduced without much changes or replacing the existing ones for considerable increase of the overall productivity as well as profitability of the farmers. 
Table 5. Grain yield and yield components of BRRI dhan62 and BR11, Rangpur, T. Aman 2015

\begin{tabular}{ccccccccc}
\hline Treat. & $\begin{array}{c}\text { Plant ht. } \\
(\mathrm{cm})\end{array}$ & $\begin{array}{c}\text { Tiller } \\
\text { hill }^{-1}\end{array}$ & $\begin{array}{c}\text { Panicle } \\
\mathrm{m}^{-2}\end{array}$ & $\begin{array}{c}\text { Grains } \\
\text { panicle }^{-1}\end{array}$ & $\begin{array}{c}\text { 1000 grain } \\
\text { weight }(\mathrm{g})\end{array}$ & $\begin{array}{c}\text { Yield } \\
\text { tha }^{-1}\end{array}$ & $\begin{array}{c}\text { Sterility } \\
(\%)\end{array}$ & $\begin{array}{c}\text { Harvest } \\
\text { index }\end{array}$ \\
\hline $\mathrm{CP}_{1}$ & 99 & 12 & 283 & 52 & 22.57 & 4.23 & 30.3 & 0.43 \\
$\mathrm{CP}_{2}$ & 101 & 11 & 267 & 57 & 22.43 & 4.19 & 28.9 & 0.42 \\
$\mathrm{FIP}$ & 112 & 16 & 317 & 78 & 24.60 & 5.95 & 20.4 & 0.50 \\
$\mathrm{FP}$ & 113 & 16 & 292 & 97 & 24.77 & 5.92 & 21.3 & 0.48 \\
\hline $\mathrm{LSD}_{0.05}$ & 2.54 & 3.83 & 55.52 & 13.27 & 1.05 & 0.26 & 3.94 & 0.068 \\
$\mathrm{CV} \%$ & 8.67 & 2.79 & 28.34 & 12.70 & 2.00 & 8.17 & 5.65 & 6.46 \\
\hline
\end{tabular}

Table 6. Rice equivalent yield (REY) under different cropping pattern, 2015-16, BRRI Rangpur

\begin{tabular}{|c|c|c|c|c|c|}
\hline $\begin{array}{c}\mathrm{C} . \\
\text { pattern }\end{array}$ & $\begin{array}{c}1^{\text {st }} \text { crop yield } \\
\left(\mathrm{t} \mathrm{ha}^{-1}\right)\end{array}$ & $\begin{array}{c}2^{\text {nd }} \text { crop yield } \\
\left(\mathrm{t} \mathrm{ha}^{-1}\right)\end{array}$ & $\begin{array}{c}3^{\text {rd }} \text { crop yield } \\
\left(\mathrm{t} \mathrm{ha}^{-1}\right)\end{array}$ & $\begin{array}{c}4^{\text {th }} \text { crop yield } \\
\left(\mathrm{t} \mathrm{ha}^{-1}\right)\end{array}$ & $\begin{array}{c}\text { REY } \\
\left(\mathrm{t} \mathrm{ha}^{-1}\right)\end{array}$ \\
\hline $\mathrm{CP}_{1}$ & BRRI dhan62=4.23 & $*$ Potato $=25.83$ & Mungbean $=0.61$ & BRRI dhan $48=3.63$ & 35.93 \\
\hline $\mathrm{CP}_{2}$ & BRRI dhan62=4.19 & $* *$ Mustard $=0.93$ & Mungbean $=0.71$ & BRRI dhan $48=3.80$ & 13.87 \\
\hline FIP & $\mathrm{BR} 11=5.95$ & Potato $=26.80$ & Maize $=8.75$ & - & 29.82 \\
\hline FP & $\mathrm{BR} 11=5.92$ & Boro $=6.21$ & - & - & 12.13 \\
\hline
\end{tabular}

Price: Rice $=14 \mathrm{~kg}^{-1}$ (Bold), and $16.25 \mathrm{~kg}^{-1}$ (Fine grain), Potato $=15 \mathrm{~kg}^{-1}$ (early), Potato $=9.40 \mathrm{~kg}^{-1}$ (late), Mustard $=50 \mathrm{~kg}^{-1}$, Mungbean $=60 \mathrm{~kg}^{-1}$, Maize $=12.5 \mathrm{~kg}^{-1}$, Assuming, $* 1$ ton Potato $=0.99$ ton rice (early), 0.62 ton rice (late), $* * 1$ ton Mustard=3.31 trice, 1 ton Mungben= 3.97 ton rice, 1 ton Maize= 0.83 ton rice.

Table 7. Total cost of production and net return under different cropping pattern (Tk. ha $\left.{ }^{-1}\right)$, BRRI Rangpur, 2015-16

\begin{tabular}{|c|c|c|c|c|c|c|c|c|c|c|c|c|}
\hline \multirow{2}{*}{$\mathrm{CP}$} & \multicolumn{2}{|c|}{$1^{\text {st }}$ crop } & \multicolumn{2}{|c|}{$2^{\text {nd }}$ crop } & \multicolumn{2}{|c|}{$3^{\text {rd }}$ crop } & \multicolumn{2}{|c|}{$4^{\text {th }}$ crop } & \multicolumn{2}{|c|}{ Total (Tk.) } & \multirow{2}{*}{$\begin{array}{l}\text { GM } \\
(\mathrm{Tk} . \\
\left.\mathrm{ha}^{-1}\right)\end{array}$} & \multirow{2}{*}{$\mathrm{BCR}$} \\
\hline & TVC & GR & TVC & GR & TVC & GR & TVC & GR & TVC & GR & & \\
\hline $\mathrm{CP}_{1}$ & 64720 & 67840 & 74160 & 78880 & 180560 & 388240 & 35200 & 36640 & 354640 & 571600 & 216960 & 1.61 \\
\hline $\mathrm{CP}_{2}$ & 64720 & 67200 & 74160 & 78240 & 41600 & 46560 & 35200 & 42720 & 215680 & 234720 & 19040 & 1.09 \\
\hline FIP & 66660 & 100480 & 180560 & 252400 & 68640 & 109600 & - & - & 323360 & 462480 & 131620 & 1.43 \\
\hline $\mathrm{FP}$ & 66660 & 100080 & 101680 & 104160 & - & - & - & - & 175840 & 204240 & 20900 & 1.16 \\
\hline
\end{tabular}

$* \mathrm{TVC}=$ Total variable cost, $\mathrm{GR}=$ Gross return $\mathrm{GM}=$ Gross margin and $\mathrm{BCR}=$ Benefit cost ratio 
Table 8. Soil fertility as influenced by different cropping pattern, BRRI Rangpur, 2015-16

\begin{tabular}{cccccccc}
\hline C. pattern & $\mathrm{pH}$ & $\mathrm{OM}$ & Total N & $\mathrm{P}(\mathrm{ppm})$ & $\begin{array}{c}\mathrm{K}(\mathrm{meqi} / \\
100 \mathrm{~g} \text { soil })\end{array}$ & $\mathrm{S}(\mathrm{ppm})$ & $\begin{array}{c}\mathrm{Zn} \\
(\mathrm{ppm})\end{array}$ \\
\hline Initial soil & 6.60 & 1.86 & 0.10 & 31.15 & 0.14 & 6.34 & 3.74 \\
$\mathrm{CP}_{1}$ & 6.43 & 2.63 & 0.13 & 69.44 & 0.24 & 13.97 & 3.92 \\
$\mathrm{CP}_{2}$ & 6.47 & 2.55 & 0.12 & 59.01 & 0.19 & 14.84 & 3.76 \\
$\mathrm{FIP}$ & 6.33 & 2.57 & 0.12 & 72.54 & 0.26 & 12.57 & 4.64 \\
$\mathrm{FP}$ & 6.56 & 2.73 & 0.14 & 53.13 & 0.18 & 11.19 & 4.26 \\
$\mathrm{LSD}_{0.05}$ & $\mathrm{NS}$ & 0.29 & $\mathrm{NS}$ & 10.56 & 0.08 & 4.17 & 0.81 \\
\hline
\end{tabular}

The lower yield of BRRI dhan62 and BR11 in T. Aman 2014 was mainly due to severe rat damage and the yield loss was not estimated. Moreover, poor tiller production as well as panicle $\mathrm{m}^{-2}$ resulted the poor yield of BR11 in 2014. Low yield of mustard was due to pod degeneration and uneven growth and for mungbean there were poor crop establishment, wilting, yellow mosaic virus and hairy cater pillar infestation. Moreover, the prevailing cold, foggy weather and low solar hours (Fig. 1 \& 2 A) in rabi season might affected the growth and yield of mustard and mungbean. The poor yield performance of mustard and mungbean affected the total REY and gross margin of 2014-15. Such type of biotic and abiotic stress reduced the crop yield and even 4 crops were not profitable $\left(\mathrm{CP}_{2}\right)$. It gave lower REY and less gross margin compared to farmers' improved practice.

There was no yield difference in early potato (1 November sowing) and late potato (20 November sowing) in that condition but the market price of early potato was higher. That was the main advantage of cultivating early potato followed by short duration rice variety.

However, 4 crops like BRRI dhan62-potatomungbean-BRRI dhan48 gave the highest REY, gross return and profit. There are some results which support the present results. The highest average gross return (Tk.5,00,480 ha ${ }^{-1}$ ) and net return (Tk.2,63,760 ha ${ }^{-1}$ ) were reported in 4 crops ((T. Aman-Potato-Mungbean-T. Aus) followed by (T. Aman-Mustard-Mungbean-T. Aus. Four crops based pattern can be recommended for higher productivity, soil enrichment and economic benefit. The cost benefit analysis showed that inclusion of potato, mustard and Aus rice in the existing pattern showed higher benefit (Mondal et al., 2015).

The gross return and gross margin were higher in improved pattern compared to that of existing farmer's pattern with only 149 and $151 \%$ extra cost at FSRD site. The higher rice equivalent yield (22.41 and $\left.21.82 \mathrm{t} \mathrm{ha}^{-1} \mathrm{yr}^{-1}\right)$ indicated the superiority of the improved pattern over the farmer's existing pattern at both sites. Higher rice equivalent yield with improved cropping pattern (4 crops) was reported suitable in Tangail region for increasing crop productivity as well as cropping intensity (Rahman et al., 2015).

Inclusion of mungbean in the wheat-rice cropping sequence showed higher production cost but it gave higher system productivity, gross return, and gross margin, this cropping sequence gave on an average $57 \%$ higher wheat equivalent yield compared to the existing wheat rice sequence followed by blackgram included cropping sequence (Hossain et al., 2016). The net return (Tk. $198320 \mathrm{ha}^{-1}$ ) of improved cropping pattern were $24.93 \%$ higher compared to that of farmers' pattern with $45.44 \%$ extra cost (Khatun et al., 2016). The maximum economic return in terms of gross return (Tk.2,26,000 ha-1) and gross margin (Tk.87,440 ha ${ }^{-1}$ ) were recorded (OFRD, 2016). Higher gross return (Tk.5,27,840 $\mathrm{ha}^{-1}$ ) and gross margin (Tk.2,50,720 ha ${ }^{-1}$ ) were obtained in improved Potato-Boro-T. Aus-T. Aman cropping pattern and lower gross return 
(Tk.4,19,120 $\mathrm{ha}^{-1}$ ) and gross margin (Tk.1,80,880 ha-1) found in existing cropping pattern. (OFRD, 2016).

Generally, the cropping pattern with higher intensity consumed the higher amount of fertilizers. In the present study, there was no big changes in soil fertility occurred after completing 2 years experiments mainly due to use of organic manure (@1 t ha $^{-1}$ ) with maintaining the recommended fertilizer rates in all crops regularly. However, the highest gross return was estimated in $25 \%$ higher dose of fertilizer recommended guide (FRG) 2012 (Tk.703520. $\mathrm{ha}^{-1}$ ) and lowest was obtained from $25 \%$ lower of FRG 2012 (Tk.6,18,320 ha ${ }^{-1}$ ).Inclusion of new crops in the existing pattern and replacing old and traditional varieties by modern improved varieties enhanced productivity and profitability. Higher REY was obtained in alternate cropping pattern due to introduction of new crop and varieties which increase $13 \%$ over existing cropping sequence (OFRD, 2015-16). Alternate cropping pattern gave higher rice equivalent yield (REY, $16.55 \mathrm{t} \mathrm{ha}^{-1} \mathrm{yr}^{-1}$ ) against existing cropping pattern (11.03 $\left.\mathrm{t} \mathrm{ha}^{-1} \mathrm{yr}^{-1}\right)$. Higher rice equivalent yield was obtained in alternate cropping pattern due to introduction of new crops and varieties. REY was found to increase by $50 \%$ over existing cropping sequence. (OFRD, 2016). Alternate cropping patterns was agronomically feasible economically profitable than existing patterns, rice equivalent yield, productivity and profitability was higher than the farmers' existing patterns (OFRD, 2017).

\section{Conclusions}

Comparing two years' results, variations in grain yields of different crops, market price of inputs and outputs were observed. Only two years' results are inadequate to draw a conclusion for such type of study. However, higher gross return and gross margin, higher cropping intensity and productivity indicated the superiority of the improved cropping pattern over farmers' practice. T. Aman (BRRI dhan62)-Potato (Cardinal)-Mungbean (BARI Mung-6)-T. Aus
(BRRI dhan48) was found to be the most suitable and profitable cropping pattern in medium high lands of Rangpur region.

\section{Acknowledgement}

The authors express their sincere gratitude to BRRI authority for all type of support to conduct this study and to Mr. Abdus Satter, Field Assistant and Mr. Roydurlov, Field Technician for data taking, management and care of the experiment.

\section{References}

BBS (Bangladesh Bureau of Statistics) 2015. Statistical Yearbook of Bangladesh. Bangladesh Bureau of Statistics, Ministry of Planning, Dhaka, Bangladesh.

Hossain, M. S., Sarker, M. A. R., Jahiruddin, M. Chaki, A. K. and Khan, ASM M. R. 2016. Productivity and partial budget analysis in wheat- rice sequences as influenced by integrated plant nutrition system and legume crops inclusion. Bangladesh Journal of Agricultural Research. 41(1): 17-39, March, 2016.

Islam, S. 1991. Soil nutrient status affecting productivity of pulses in the major and potential pulse-growing areas. In: Advances in Pulses Research in Bangladesh. Proceedings of the $2^{\text {nd }}$ national workshop on pulses, June 6-8, 1989, BARI, Gazipur. Published by ICRISAT, Patancheru, Andhra Pradesh 502 324, India.

Khan, M. A. H., Quayyum, M. A., Nazrul, M. I., Sultana, N. \& Mollah, M. R. A. (2005). On-Farm evaluation of production potential and economics mustard-rice based improved cropping system. Bangladesh J. Socio. Res. Dev. 2(1), $37-$ 42 .

Khatun, M.U.S., Alam, M.A.U., Islam, M.K., Hossain, A.M.M.A. and Haque, M. E. 2016. Evaluation of production potential and economics of Radish-Potato/Maize- 
T.Aman cropping pattern in Rangpur Region. Journal of Science, Technology and Environment Informatics. 04(02): 293-300.

Mondal, R.I, F. Begum, Aziz, A. and Sharif, S. H. 1015. Crop sequences for increasing cropping intensity and productivity. SARC Journal of Agriculture, 13(1): 135-147.

Nazrul, M. I., Shaheb, M. R., Khan, M. A. H. \& Khan, A. S. M. M. R. 2013. On-Farm Evaluation of production potential and economic returns of potato-rice based improved cropping system. Bangladesh Agronomy Journal, 16(2), 41-50.

OFRD (On-Farm Research Division), 2016. Improvement of existing cropping pattern with introducing short duration modern crop varieties. Annual Research Report, OFRD, BARI. 41-96 pp.

OFRD (On-Farm Research Division), 2014. Improvement of Mustard-Boro-T.Aman cropping pattern Mustard-Boro-Jute-T. Aman. Annual Research Report, OFRD, BARI.
OFRD (On-Farm Research Division), 2017. Performance of four crop based cropping patterns against farmers' existing pattern in different agro-ecological zones of Bangladesh. Paper presented in national workshop on "Increasing cropping intensity and productivity with 4 crops based pattern program" held at BARI, Joydebpur on 4 March, 2017.

Rahman, M. M., Rahman, M. A. Ahmed, M. Uddin, M. M. and Choudhury, A. K. 2015. Improvement from mustard-boro-T. Aman cropping pattern to mustard-borojute-T. Aman. Bangladesh Journal of Agricultural Research. 40(2): 259-270.

Sharma, S. N. and Prasad, R. 1999. Effects of sesbania green manuring and mungbean residue incorporation of productivity and nitrogen uptake of a rice-wheat cropping system. Bioresource Technology, 67 (2): 171-175.

Verma, S.P and Modgal, S.C. 1983. Production potential and economics of fertilizer application as resources constraints in maize, wheat crop sequences. Himachal Journal of Agricultural Research. 9(2): 89-92. 